\title{
Control Analysis of Stand-Alone Wind Power Supply System with Three Phase PWM Voltage Source Inverter and Boost Converter
}

Tin Zar Khaing, Lwin Za Kyin

Department of Electrical Power Engineering, Mandalay Technological University Mandalay, Myanmar

\begin{tabular}{l} 
Article Info \\
\hline Article history: \\
Received Apr 2, 2015 \\
Revised May 15, 2015 \\
Accepted Jun 2, 2015 \\
\hline Keyword: \\
DC-DC Boost Converter \\
Diode Rectifier \\
LC Filter \\
Permanent Magnet \\
Pulse Width Modulation \\
Synchronous Generator \\
Voltage Source Inverter
\end{tabular}

\section{Corresponding Author:}

Tin Zar Khaing, Department of Electrical Power Engineering, Mandalay Technological University Mandalay, Myanmar.

Email: tinzakhaing.ep@gmail.com

\begin{abstract}
Wind power supply system is an effective, environmentally friendly power source for household and other applications. According to the wind speed changes in variation the output power of wind generator is not stable and constant. This paper proposes the variable speed stand-alone wind power supply system that includes Permanent Magnet Synchronous Generator, three phase diode rectifier, DC-DC boost converter, battery energy storage system, and voltage source inverter. DC-DC boost converter controls to extract maximum power from the available wind power. Battery energy storage system through bidirectional converter is to supply the load when wind power is shortage. To get the desired output voltage and frequency at the load side, the voltage source inverter with the sinusoidal pulse width modulation (SPWM) control technique has chosen. The harmonics generated from the VSI are filtered with simple passive LC filters. Simulation results of output voltages and currents, the total harmonic distortion (THD) are presented using MATLAB/Simulink.
\end{abstract}

Copyright (C) 2015 Institute of Advanced Engineering and Science. All rights reserved.

\section{INTRODUCTION}

Renewable energy sources including wind power offer a feasible solution to distributed power generation for isolated communities where utility grids are not available. In such cases, stand-alone wind energy systems can be considered as an effective way to provide continuous power to electrical loads. For isolated places located far from a utility grid, one practical approach to self-sufficient power generation involves using a wind turbine with stand-alone system [1].

Modern wind turbine systems use three phase AC generators as follows:

- Squirrel-Cage rotor Induction Generator

- Wound-Rotor Induction Generator

- Doubly-Fed Induction Generator

- Synchronous Generator with external field excitation

- Permanent Magnet Synchronous Generator.

Normally, there are two operating modes of wind turbine generators system such as fixed speed and variable speed operating modes. Variable speed wind energy systems have several advantages compared with fixed speed wind energy systems such as yielding maximum power output, developing low amount of mechanical stress, improving efficiency and power quality [2]. As wind speed is not constant, generator output is fluctuated. In order to achieve the stable power at the load side under the condition that the generator output power is variable, it is necessary to use a controller to get the stable output produced by the 
wind turbine generator. The reliability of the variable speed wind energy systems can be improved significantly by using a permanent magnet synchronous generator (PMSG). The control scheme for the overall system is mainly classified as supply side control and load side control.

\section{STAND-ALONE WIND POWER SUPPLY SYSTEM}

In this stand-alone system, three blade wind turbine with horizontal axis is directly connected with PMSG without using gearbox. The output of PMSG flows through three phase diode rectifier, DC-DC boost converter, battery, and voltage source inverter to the load. As the available wind speed is not constant, the boost circuit is employed to extract maximum power from available wind power. Battery energy storage system is to supply load when the wind power is shortage. A three phase inverter is connected to the load through LC filter. The overall schematic diagram of the proposed system is shown in Figure 1.

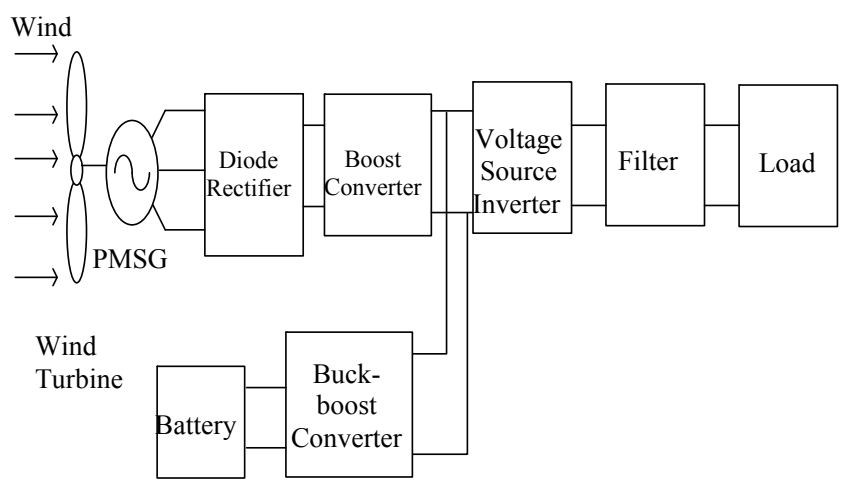

Figure 1. Schematic diagram of the proposed system

\subsection{Wind Turbine Model}

The most important technical information for a specific wind turbine is the power curve which shows the relationship between wind speed and the electrical power output of the generator. There are three types of wind speeds: cut-in wind speed, rated wind speed, and cut-out wind speed. The cut-in wind speed is the minimum wind speed needed to generate net power. The generator is delivering as much power as it is designed for when the wind speed reach at the rated speed. At cut-out wind speed, the machine must be shut down [3].

The mechanical power captured from wind turbine is governed by the following equation:

$$
\mathrm{P}_{\mathrm{m}}=0.5 \rho \mathrm{AC}_{\mathrm{p}} \mathrm{V}_{\mathrm{w}}^{3}
$$

Where $\mathrm{P}_{\mathrm{m}}$ is the mechanical output power of the wind turbine (Watt), $\rho$ is the air density $\left(\mathrm{Kg} / \mathrm{m}^{3}\right), \mathrm{A}$ is the swept area $\left(\mathrm{m}^{2}\right), C_{p}$ is the power coefficient of the wind turbine and $V_{w}$ is the wind speed $(\mathrm{m} / \mathrm{s})$. The efficiency of a wind turbine includes the loss in the mechanical transmission, electrical generation, converter loss, etc., where as the power coefficient is the efficiency of converting the power in the wind into mechanical energy in the rotor shaft. The power coefficient is usually given as a function of the tip speed ratio $\lambda$ and the blade pitch angle $\beta$. If $\beta$ is equal zero, in this case, $C_{p}$ and $\lambda$ are given as:

$$
\begin{aligned}
& \mathrm{C}_{\mathrm{p}(\lambda)}=\frac{60.04-4.69 \lambda}{\lambda} \mathrm{e}^{\left[\frac{-21+0.735 \lambda}{\lambda}\right]}+\frac{0.0068 \lambda}{1-0.035 \lambda} \\
& \lambda=\frac{\omega_{\mathrm{r}} \mathrm{R}}{\mathrm{V}_{\mathrm{w}}}
\end{aligned}
$$


Where $\omega_{\mathrm{r}}$ is the rotational speed $(\mathrm{rad} / \mathrm{s})$ and $\mathrm{R}$ is the radius of blade $(\mathrm{m})$. Maximum power from wind turbine can be extracted when the turbine operate at maximum $\mathrm{C}_{\mathrm{p}}\left(\mathrm{C}_{\mathrm{p} \text {-opt }}\right)$. The optimum value of $\mathrm{C}_{\mathrm{p}}$ is about 0.48 for $\lambda$ equal 8.1 by assuming $\beta$ is equal to zero degree. Therefore, it is necessary to adjust the rotor speed at optimum value of tip speed ratio $\left(\lambda_{\text {opt }}\right)$ with wind speed variation to extract maximum power from wind turbine [2].

\subsection{Permanent Magnet Synchronous Generator (PMSG)}

The PMSG differs from the induction generator in that the magnetization is provided by a permanent magnet pole system on the rotor, instead of taking excitation current from the armature winding terminals, as it is the case with the induction generator. The advantages of permanent magnet machines over electrically excited machines are that they have higher efficiency and energy yield. They do not need additional power supply for the magnet field excitation. Due to the absence of the field winding and mechanical components such as slip rings, it has smaller losses and higher reliability [1]. The mathematical model of the PMSG in the synchronous reference frame (in the state equation form) is given by,

$$
\begin{aligned}
& \frac{\mathrm{di}_{\mathrm{d}}}{\mathrm{dt}}=\frac{1}{\mathrm{~L}_{\mathrm{ds}}} \mathrm{v}_{\mathrm{d}}-\frac{\mathrm{r}_{\mathrm{s}}}{\mathrm{L}_{\mathrm{ds}}} \mathrm{i}_{\mathrm{d}}+\frac{\mathrm{L}_{\mathrm{qs}}}{\mathrm{L}_{\mathrm{ds}}} \omega_{\mathrm{e}} \mathrm{i}_{\mathrm{q}} \\
& \frac{\mathrm{di}_{\mathrm{q}}}{\mathrm{dt}}=\frac{1}{\mathrm{~L}_{\mathrm{qs}}} \mathrm{v}_{\mathrm{q}}-\frac{\mathrm{r}_{\mathrm{s}}}{\mathrm{L}_{\mathrm{qs}}} \mathrm{i}_{\mathrm{q}}-\frac{\mathrm{L}_{\mathrm{ds}}}{\mathrm{L}_{\mathrm{qs}}} \omega_{\mathrm{e}} \mathrm{i}_{\mathrm{d}}-\frac{\psi_{\mathrm{f}} \omega_{\mathrm{e}}}{\mathrm{L}_{\mathrm{qs}}} \\
& \mathrm{T}_{\mathrm{e}}=1.5\left(\left(\mathrm{~L}_{\mathrm{ds}}-\mathrm{L}_{\mathrm{qs}}\right) \mathrm{i}_{\mathrm{d}} \mathrm{i}_{\mathrm{q}}+\mathrm{i}_{\mathrm{q}} \psi_{\mathrm{f}}\right.
\end{aligned}
$$

Where, $L_{d}, L_{q}$ are $d$ and $q$ axis inductances, $R$ is stator winding resistance, $i_{d}, i_{q}$ are $d$ and $q$ axis currents, $v_{\mathrm{q}}, \mathrm{v}_{\mathrm{d}}$ are $\mathrm{d}$ and $\mathrm{q}$ axis voltage, $\omega_{\mathrm{r}}$ is angular velocity of rotor, $\lambda$ is amplitude of rotor induced flux, $p$ is pole pair number, and $T_{e}$ is electromagnetic torque. Table I show the parameters of wind turbine with PMSG which are applied to the simulation model of the proposed system.

Table 1. Parameters of Wind Turbine and Generator

\begin{tabular}{cc}
\hline Parameters & Rating \\
\hline Rated wind speed & $10 \mathrm{~m} / \mathrm{sec}$ \\
Cut-in wind speed m/sec & $5 \mathrm{~m} / \mathrm{sec}$ \\
Cut-out wind speed & $25 \mathrm{~m} / \mathrm{sec}$ \\
Blade diameter & $10 \mathrm{~m}$ \\
Power coefficient & 0.48 \\
Swept area & $78.5 \mathrm{~m}^{2}$ \\
Turbine rated speed & $167 \mathrm{rpm}$ \\
Rated power & $20 \mathrm{~kW}$ \\
frequency & $50 \mathrm{~Hz}$ \\
Pole pairs & 18 \\
$\mathrm{R}_{\mathrm{s}}$ & $0.5 \Omega$ \\
$\mathrm{L}_{\mathrm{s}}$ & 0.448 \\
\hline
\end{tabular}

\section{SUPPLY SIDE SONVERTER CONTROL}

The supply side converter control involved control of three phase diode rectifier, DC-DC boost converter and DC-DC bidirectional buck-boost converter.

\subsection{Diode Rectifier}

The three phase full-wave bridge rectifier can be connected directly to the three phase source. The average output voltage of the rectifier and the filter capacitor to eliminate the output voltage ripples are:

$$
\mathrm{V}_{\mathrm{dc}}=(3 \sqrt{2} / \pi) \mathrm{V}_{\mathrm{LL}}
$$




$$
\mathrm{C}_{1}=1 / \mathrm{f}_{\mathrm{r}} \mathrm{R} \mathrm{R}_{\mathrm{f}}
$$

Where $V_{d c}$ is DC or average output voltage, $V_{L L}$ is AC line voltage, $f_{r}$ is ripple frequency, $R$ is resistance, and $\mathrm{R}_{\mathrm{f}}$ is ripple factor.

\subsection{DC-DC Boost Converter Control}

The input to this converter is an unregulated DC voltage which can be obtained by rectifying an AC voltage source. This unregulated voltage will fluctuate due to changes in the line due to the fluctuation of wind speed. In order to control this unregulated DC voltage into a regulated DC output it is needed to use a DC-DC boost converter. The converter consists of an inductor L, an insulated gate bipolar transistor (IGBT), a diode, and a filter capacitor $\mathrm{C}$. Filters made of capacitors are normally added to the output of the converter to reduce output voltage ripple .The circuit diagram of DC-DC boost converter is shown in Figure 2. When the IGBT switch is closed, the energy stored in the inductor increase. When it is opened, the stored energy has to transfer to the diode, capacitor and load [4].

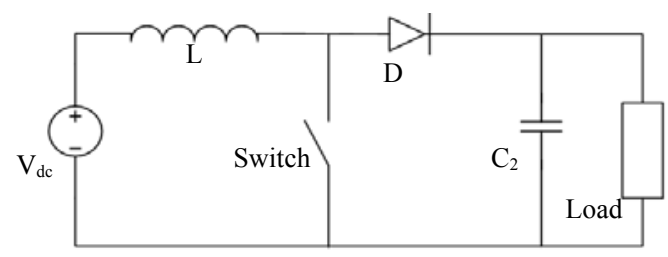

Figure 2. Circuit diagram of DC-DC boost converter

The boost converter output voltage is obtained as:

$$
\begin{aligned}
& \mathrm{V}_{\mathrm{o}}=\mathrm{V}_{\mathrm{i}} /(1-\mathrm{D}) \\
& \mathrm{M}_{\mathrm{VDC}}=\mathrm{V}_{\mathrm{o}} / \mathrm{V}_{\mathrm{I}}=\mathrm{I}_{\mathrm{I}} / \mathrm{I}_{\mathrm{o}}=1 /(1-\mathrm{D}) \\
& \mathrm{L}_{1}=(2 / 27)\left(\mathrm{V}_{\mathrm{o}} / \mathrm{f}_{\mathrm{s}} \mathrm{I}_{\mathrm{omax}}\right) \\
& \mathrm{C}_{2}=\left(\mathrm{D}_{\max } \mathrm{V}_{\mathrm{o}}\right) /\left(\mathrm{f}_{\mathrm{s}} \mathrm{R}_{\mathrm{Lmin}} \mathrm{V}_{\mathrm{cpp}}\right)
\end{aligned}
$$

Where, $\mathrm{V}_{\mathrm{o}}$ is output voltage, $\mathrm{V}_{\mathrm{i}}$ is input voltage, $\mathrm{D}$ is duty cycle, $\mathrm{M}_{\mathrm{VDC}}$ is $\mathrm{DC}$ voltage transfer function, $\mathrm{f}_{\mathrm{s}}(1 \mathrm{kHz})$ is switching frequency, $\mathrm{L}_{1}$ is minimum inductance, $\mathrm{I}_{\text {omax }}$ is maximum output current. $\mathrm{C}_{2}$ is minimum filter capacitance, and $\mathrm{R}_{\mathrm{Lmin}}$ is minimum load resistance. The block diagram of the DC-DC boost controller is shown in Figure 3.

In this DC-DC boost converter control, Pulse Width Modulation (PWM) control method is used to extract maximum power from the available wind power. For this system, the reference voltage of $566 \mathrm{~V}$ is used to control the DC voltage at the rectifier DC side terminals. The reference voltage is compared with the actual voltage from the diode rectifier, and the error signal is fed to a PI controller. The output of PI controller is compared with carrier triangular wave by passing comparator to control the duty cycle of the IGBT switch. 


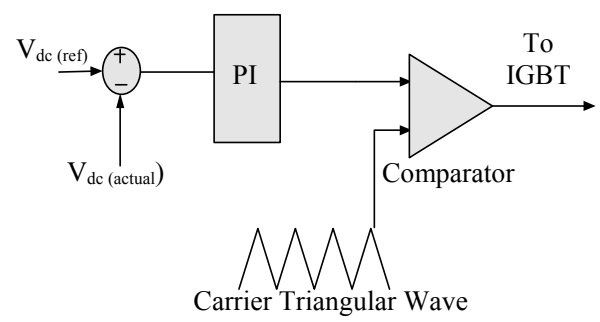

Figure 3. Block diagram of typical DC-DC boost converter controller

\subsection{DC-DC Bidirectional Buck-Boost Converter Control}

The DC-DC bidirectional buck-boost PWM converter is used to perform the charge and discharge function to the battery bank. The function of the controller is that the reference voltage $\left(\mathrm{V}_{\mathrm{dc}-\mathrm{ref}}\right)$ of the converter is compared with the actual dc voltage $\left(\mathrm{V}_{\mathrm{dc} \text {-actual }}\right)$. The error signal is processed through the PI controller. The limiter limits the output of PI controller and compare with the high frequency saw tooth wave to generate the duty cycle of the switches $\mathrm{Q}_{1}$ and $\mathrm{Q}_{2}$. When wind power output is greater than the load demand, the switch, $\mathrm{Q}_{1}$ is on, the converter operates the buck function and charges to the battery bank. When the wind power output is less than the load demand, the switch, $\mathrm{Q}_{2}$ is on, the converter operates as boost mode and discharges to the DC link. The control strategy for the battery energy storage system is shown in Figure 4.

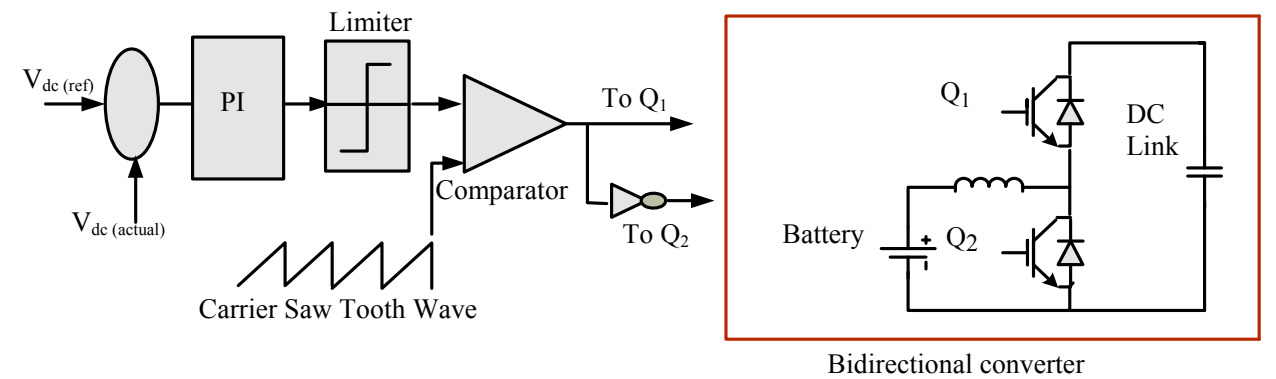

Figure 4. Bidirectional converter control for the battery energy storage system

The battery bank voltage can be kept lower than the reference DC link voltage (566 V) via DC-DC bidirectional buck-boost PWM converter and hence less number of batteries need to be connected in series. In the simulink model, the battery bank voltage is kept at $300 \mathrm{~V}$ for this system which can continuously supply $10 \mathrm{~kW}$ load nearly two hour when wind power is shortage. The depth of discharge (DOD) of the battery is considered at $80 \%$.

\section{LOAD SIDE INVERTER CONTROL}

Based on the power supply, inverters can be broadly classified into two types: voltage source inverter (VSI) and current source inverter (CSI). VSI has a small or negligible impedance at its input terminal which has a stiff de voltage source, whereas for a CSI, it is fed with adjustable current from a dc source with high impedance. The output voltage can be varied by varying the input dc voltage and keeping constant inverter gain, however, if the input dc voltage is fixed and cannot be controlled, the gain of the inverter has to be varied to obtain variable output voltage. Varying the gain of the inverter is mainly done by a scheme which is known as pulse width modulation [5].

Different control methods of inverter used in wind turbine are: (i) Sinusoidal pulse width modulation (SPWM), (ii) Hysteresis Current Controller, (iii) Space vector pulse width modulation (SVPWM). PWM techniques are represented by fixed amplitude pulses. This is the most suitable method of controlling output voltage. 


\subsection{Voltage Source Inverter Control with SPWM}

Power MOSFET and IGBT switches are largely used power semiconductor devices for inverters. As the IGBT combines low on-state voltage drop and high off-state voltage characteristics of BJT and high input impedance of the MOSFET, IGBT is chosen as power semiconductor switch. The parameters of $\mathrm{K}_{\mathrm{p}}=10$ and $\mathrm{K}_{\mathrm{i}}=0.01$ are used for simulation studies. The circuit diagram of the three phase VSI is shown in Figure 5.

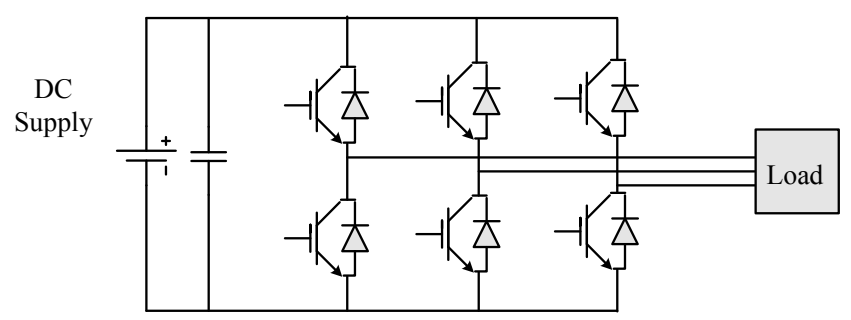

Figure 5. Circuit diagram of three phase voltage source inverter

In this SPWM control technique, three phase voltage $\left(\mathrm{V}_{\mathrm{abc}}\right)$ is transformed to $\mathrm{V}_{\mathrm{dq}}$ and it is compared with reference $V_{d q}$. The error signal is fed to the PI controller. Then it is retransformed to $V_{a b c}$. The result reference voltages of variable amplitude and frequency are compared with carrier triangular wave of fixed amplitude and frequency in three separate comparators. The comparators generate switching signal to the corresponding inverter leg. Switches of any leg of the inverter cannot be switched on at the same time since this would result in a short circuit across the de link voltage supply. NOT gates are used to avoid this condition as shown in Figure 6.

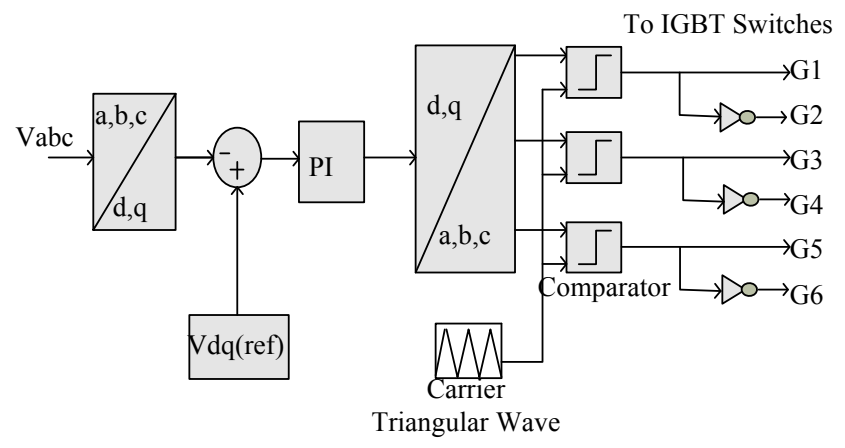

Figure 6. Control signal generation for SPWM

The carrier and reference waves are mixed in a comparator. The comparators give the pulses when sinusoidal wave is greater than the triangular wave. In this case, the modulation index $\mathrm{m}_{\mathrm{a}}$ is defined as,

$$
\mathrm{m}_{\mathrm{a}}=\frac{\mathrm{V}_{\mathrm{m}(\text { reference })}}{\mathrm{V}_{\mathrm{m}(\text { carrier })}}
$$

The normalized carrier frequency $\mathrm{m}_{\mathrm{f}}$ is

$$
\mathrm{m}_{\mathrm{f}}=\frac{\mathrm{f}_{\text {(carrier) }}}{\mathrm{f}_{\text {(reference) }}}
$$

Since the output of the inverter is affected by the switching frequency it will contain harmonics. Filters are needed to eliminate the harmonics. 


\subsection{Passive Filters}

The load side voltage source inverter generates unwanted high frequency harmonics. These harmonics can be eliminated by using filters. RC and LC filters are the most widely used passive filters for inverter. They are divided into $1^{\text {st }}$ order, $2^{\text {nd }}$ Order and $3^{\text {rd }}$ order filters according to the combination of the passive components. LC is a $2^{\text {nd }}$ order filter and LCL is the $3^{\text {rd }}$ order filter [6]. The $2^{\text {nd }}$ order low pass LC filter is used for this research. The capacitor maintains the load voltage constant whereas the inductor makes the current smoother [7]. Typically the ripple current can be chosen as $10 \%$ to $15 \%$ of rated current. Considering $10 \%$ ripple at the rated current, the designed value of inductor in the system is given by [9]:

$$
\mathrm{L}=\frac{\mathrm{V}_{\mathrm{DC}}}{8 \Delta \mathrm{I}_{\mathrm{L}} \mathrm{f}_{\mathrm{s}}}
$$

The capacitor is designed based on reactive power supplied by the capacitor at fundamental frequency. In this design, reactive power can be chosen as $15 \%$ of the rated power and the capacitor is given by [8]:

$$
\mathrm{C}=\frac{15 \% \times \mathrm{P}_{\text {rated }}}{3 \times 2 \pi \times \mathrm{V}_{\text {rated }}^{2}}
$$

Where, $\mathrm{f}_{\mathrm{s}}$ is switching frequency, $\mathrm{V}_{\mathrm{DC}}$ is $\mathrm{DC}$ link voltage, $\mathrm{L}$ is filter inductor. $\mathrm{P}_{\text {rated }}$ is rated power, $\mathrm{V}_{\text {rated }}$ is rated voltage, $\mathrm{f}$ is nominal frequency and $\mathrm{C}$ is filter capacitor. Total harmonic distortion (THD) is measured by the ratio of distortion voltage or current to fundamental sinusoidal input current is defined as:

$$
\% \text { THD }=100 \frac{I_{\text {dis }}}{I_{\text {sl }}}
$$

\section{RESULTS OF SIMULATION MODEL FOR THE PROPOSED SYSTEM}

The proposed overall control model for the stand-alone variable speed wind energy supply system is simulated in MATLAB/SIMULINK under different wind speed variation conditions as shown in Figure 7.

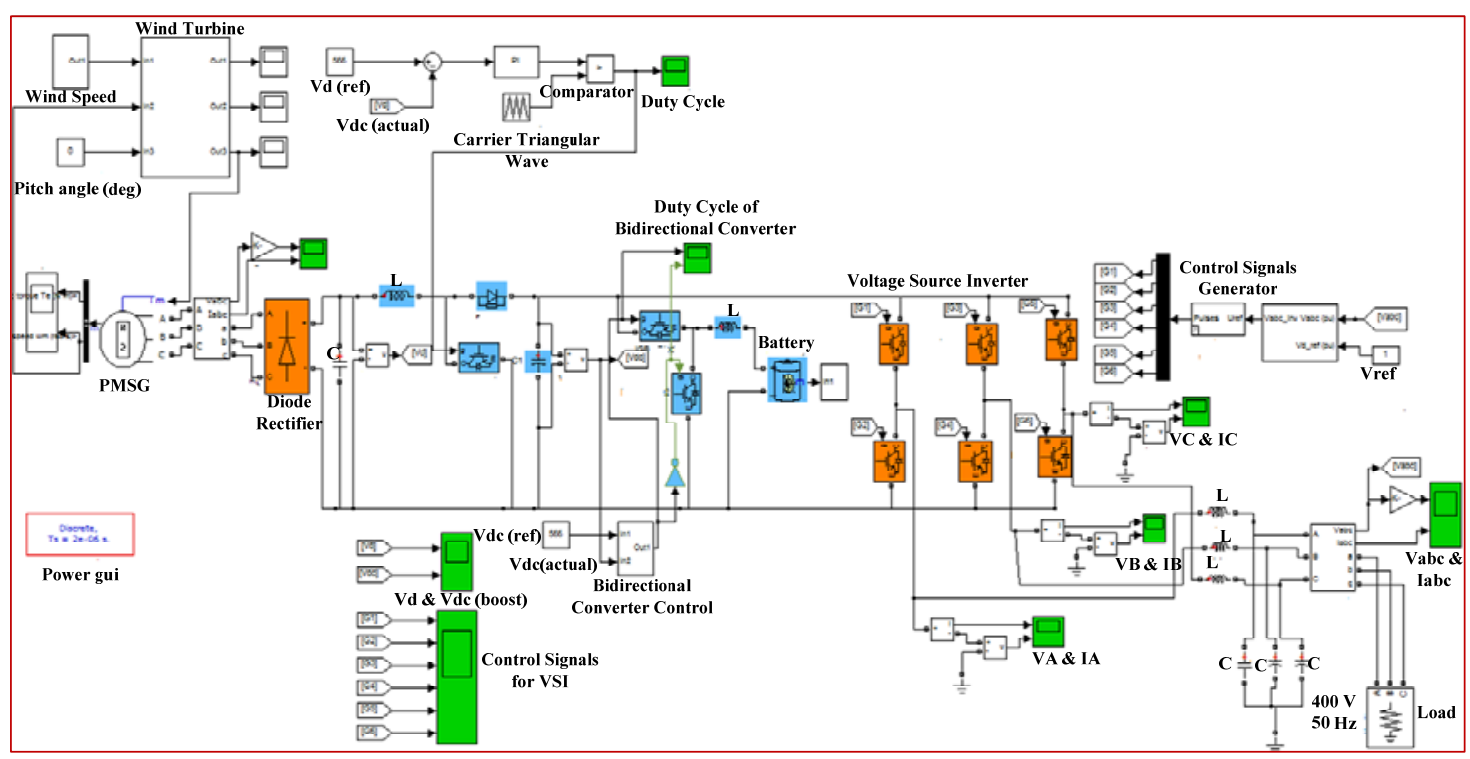

Figure 7. Simulink model of variable speed stand-alone wind power supply system

The simulated results of generator output voltage and current according to the wind speed changes are shown in Figure 8 which provides the fluctuated geneator output voltage and current when the wind speed vary between the turbine cut-in and rated wind speed. When the wind speed is lower than the rated

Control Analysis of Stand-Alone Wind Power Supply System with Three Phase PWM ...(Tin Zar Khaing) 
speed, the turbine generator cannot produce the rated power. To generate the rated voltage at low wind speed, therefore, DC-DC boost converter is used to get stable DC link voltage.
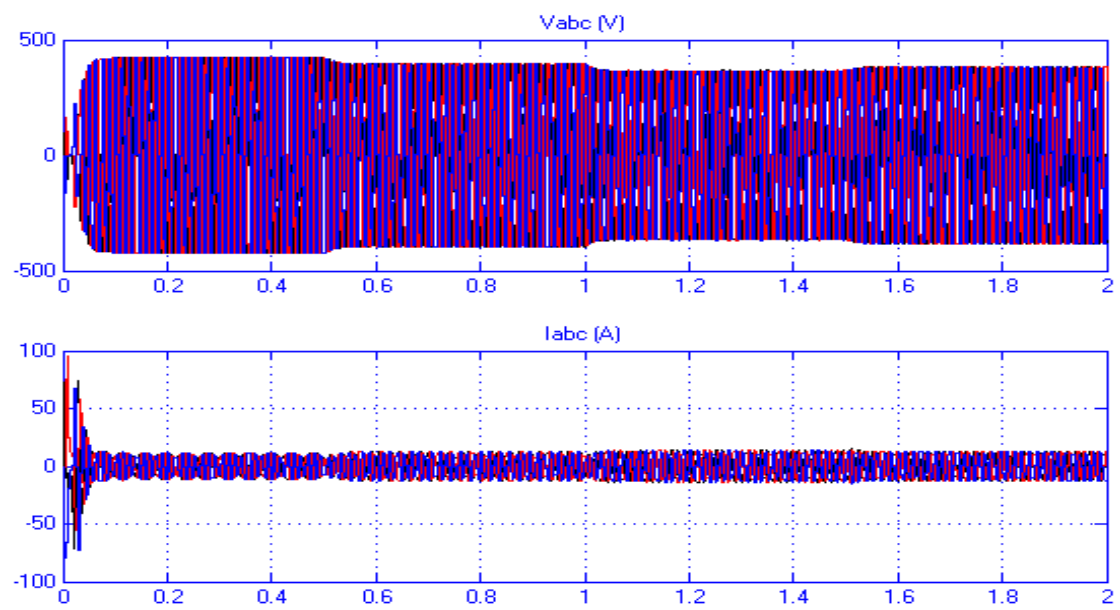

Figure 8. Simulation result of generator output voltage and current

Figure 9 gives the output voltage of diode rectifier. It can be seen that the output voltage of diode rectifier is $566 \mathrm{~V}$ at the wind speed of $10 \mathrm{~m} / \mathrm{s}$ and it decreases when the wind speed is lower. The duty cycle of the IGBT switch of DC-DC boost converter shown in Figure 10 observes that the lower the wind speed, the larger the duty cycle of the IGBT switch. The output voltage of the DC-DC boost converter is nearly stable at $566 \mathrm{~V}$ as shown in Figure 11.

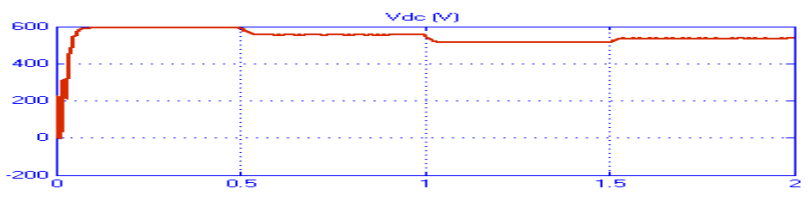

Figure 9. Simulation result of rectifier output voltage (Under the wind speed variation between cut-in and rated speed)

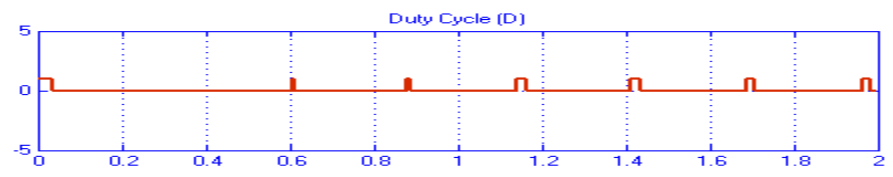

Figure 10. Simulation result of duty cycle of the boost converter

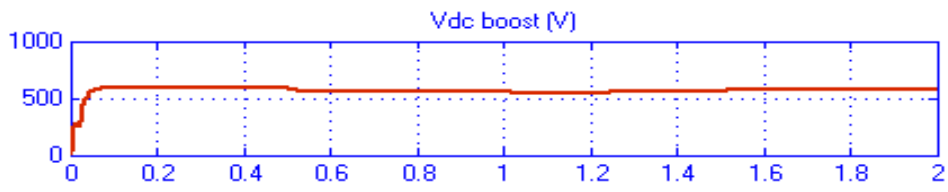

Figure 11. Simulation result of DC-DC boost converter output voltage (V) 

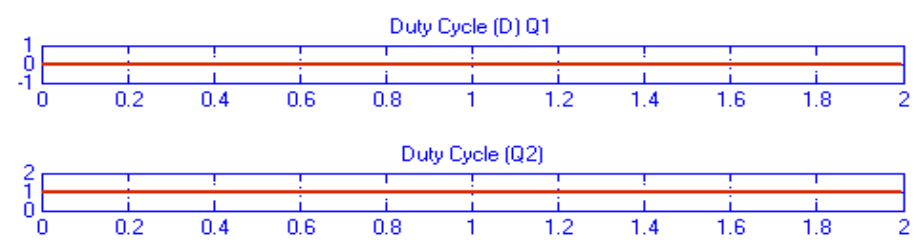

Figure 12. Simulation result of duty cycle of the bidirectional converter (Under the wind speed variation between cut-in and rated speed)

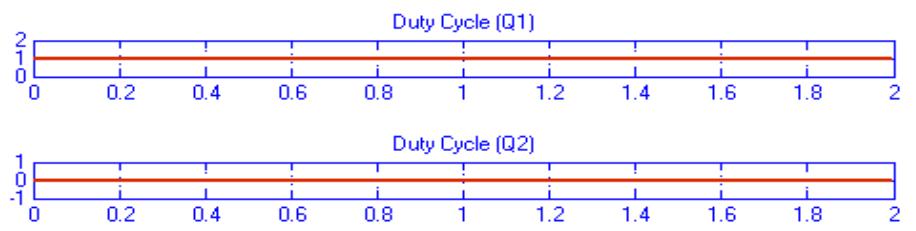

Figure 13.Simulation result of duty cycle of the bidirectional converter (When wind power output is greater than the load demand)

Figure 12 and Figure 13 illustrate the performance of bidirectional converter for the battery energy storage system. In Figure 12, the switch $\mathrm{Q}_{2}$ is on and $\mathrm{Q}_{1}$ is off resulting the battery not to be charged as there is no surplus energy, thus the stored energy is discharged from the battery during the wind speed variation between cut-in and under rated wind speed. If the system produces power greater than the load demand, the switch $\mathrm{Q}_{1}$ is on and $\mathrm{Q}_{2}$ is off during the low demand load. During this condition, the bidirectional converter operates as buck mode as seen in Figure 13, and the surplus energy is flow through the converter to store in the battery.

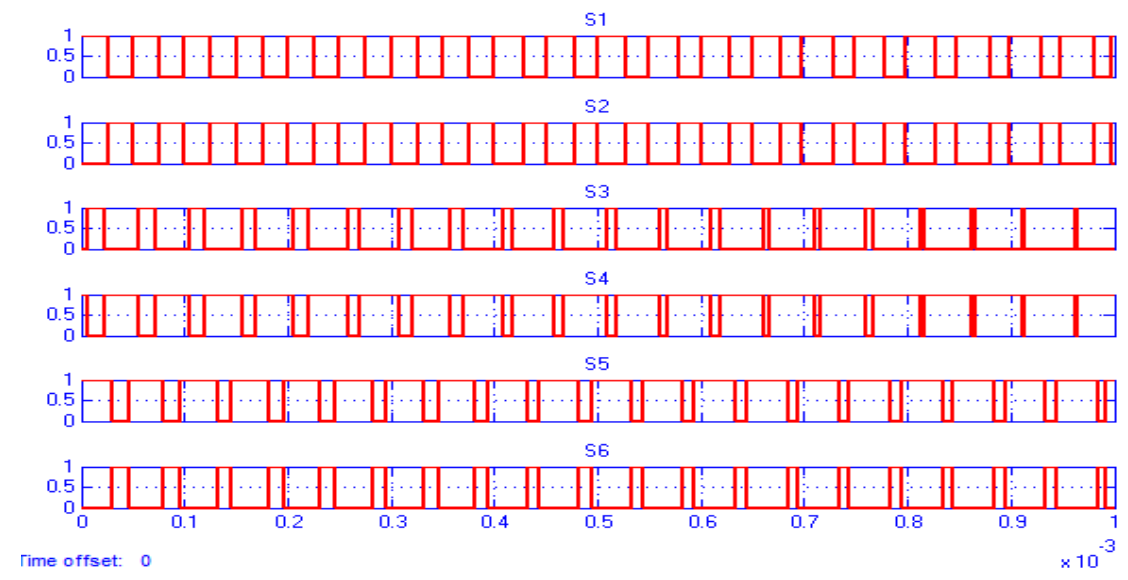

Figure 14. Simulation result of gate signals for inverter IGBT switches

The switching states or gate signals of the inverter IGBT switches are shown in Figure 14. It is noticed that the two switches of the same leg are no turned on at the same time. The output voltages of the inverter, $\mathrm{V}_{\mathrm{A}}, \mathrm{V}_{\mathrm{B}}$, and $\mathrm{V}_{\mathrm{C}}$ are simulated and observed for $0.2 \mathrm{~s}$ in Figure 15. 


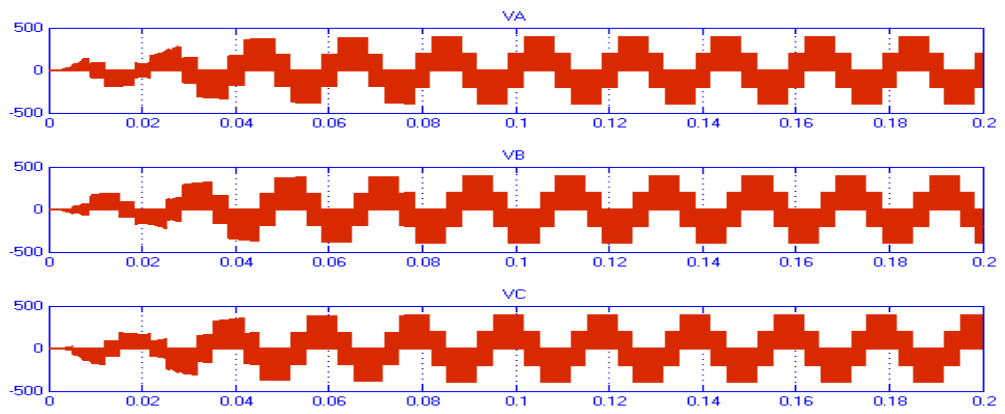

Figure 15. Simulation result of three phase inverter output

The load voltage and current without using LC filters are simulated in Figure 16 which contains the voltage and current harmonics, so filter needs to remove these harmonics. By using low pass passive filter, the content harmonics are attenuated as shown in Figure 17.
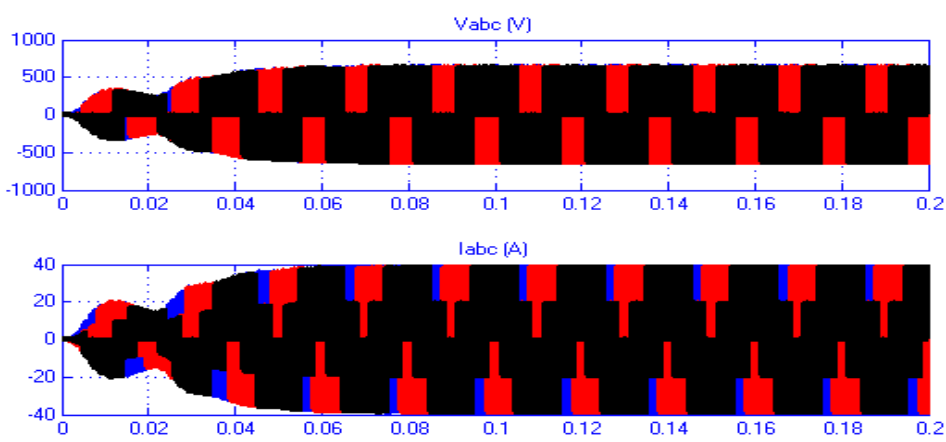

Figure 16. Simulation result of the output load voltage and current without filter
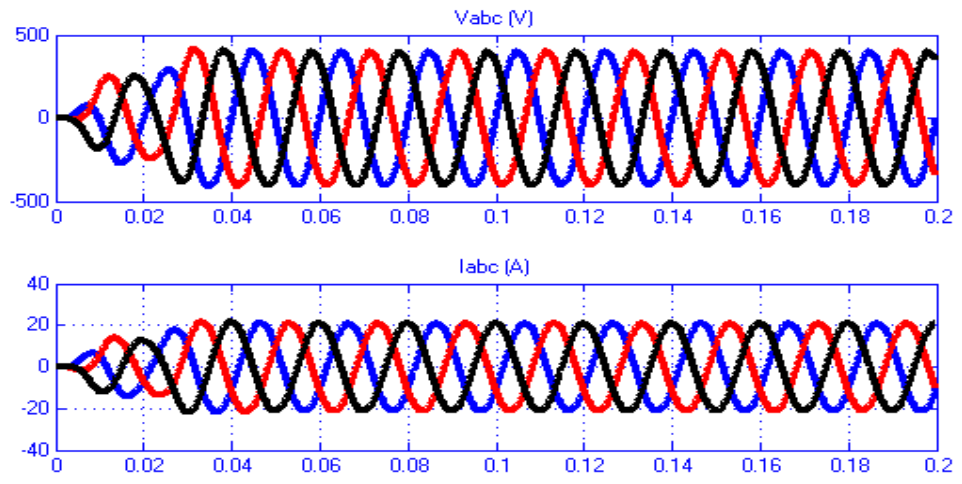

Figure 17. Simulation result of the output load voltage and current with filter

The total harmonic distortion (THD) causes adverse effects to customer loads. Thus, THD of load voltage and current with and without filters are studied with FFT analysis. The FFT analysis of load voltage and current without using the filter is performed in Figure 18 and Figure 19 which mention that the THD of load voltage and current are $66.44 \%$ and $64 \%$ respectively. Attenuation of these harmonics is achieved by an LC filter as presented in the simulink model. 


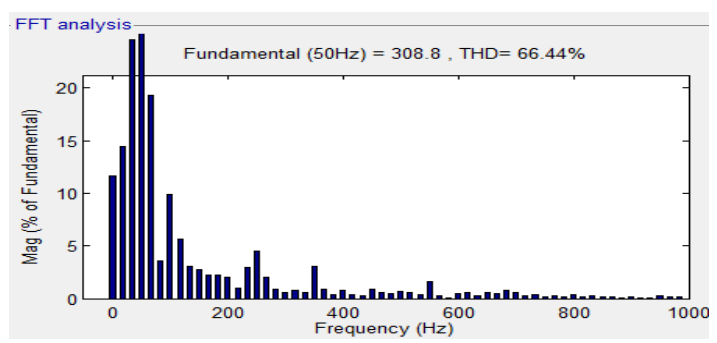

Figure 18. FFT analysis of $\mathrm{V}_{\text {load }}$ without filter form MATLAB simulink

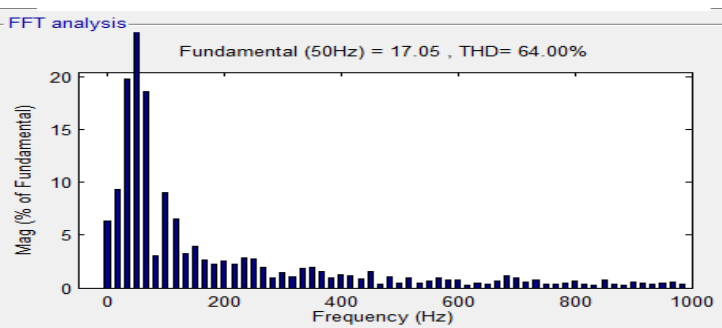

Figure 19. FFT analysis of $\mathrm{I}_{\text {load }}$ without filter from MATLAB simulink

In Figure 20 and Figure 21, the FFT analysis of load voltage and current is observed after using filters of which THD shows $9.99 \%$ for $\mathrm{V}_{\text {load }}$ and $11.01 \%$ for $\mathrm{I}_{\text {load. }}$ It is clear that the low pass passive LC filter reduced THD of load voltage and current to over $50 \%$.

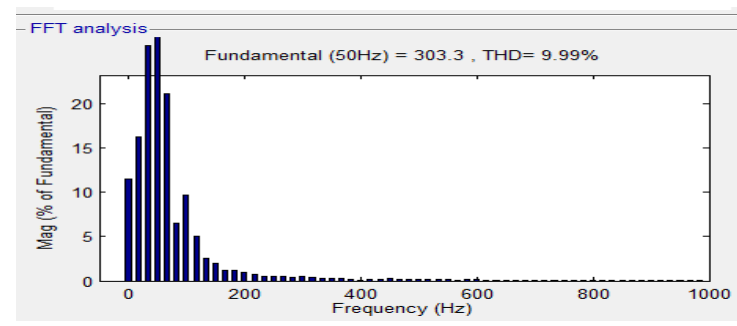

Figure 20. FFT analysis of $\mathrm{V}_{\text {load }}$ with filter form MATLAB simulink

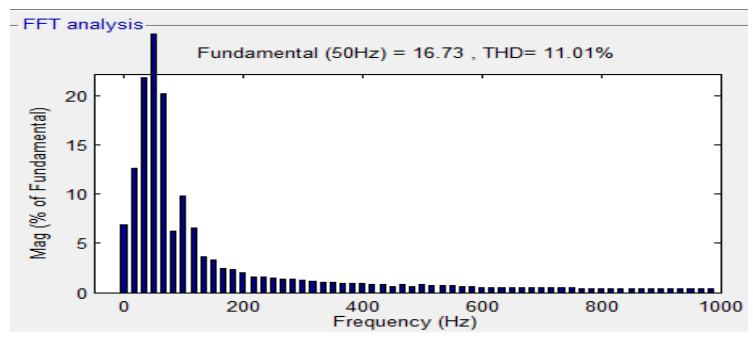

Figure 21. FFT analysis of $\mathrm{I}_{\text {load }}$ with filter from MATLAB simulink

\section{DISCUSSION AND CONCLUSIONS}

The proposed system can be used in remote places that the utility grid is not available where the available average monthly wind speed is above $5 \mathrm{~m} / \mathrm{s}$. The control of the overall system for the proposed wind power supply is modelled and simulated with MATLAB simulink. The results obtain and maintain the DC link stable voltage at $566 \mathrm{~V}$ under the variation of wind speed. The battery can supply power to the load via bidirectional converter when wind power is shortage. 
Through the three phase voltage source inverter, the stable voltage $(400 \mathrm{~V})$ is supplied to the $18 \mathrm{~kW}$ load. The load supply voltage will maintain stable with the load fluctuation under $20 \mathrm{~kW}$ by controlling the inverter with SPWM control technique between the wind speed variation of cut-in and rated wind speed. If the load increases over $20 \mathrm{~kW}$, the system will face the behaviour of system dynamic which cause the unstable voltage supply to the load. This option is not developed in these presented results.

When the load demand is low and battery is fully charged under rated wind speed, the system may produce excess energy to a certain period. It is better to incorporate the dump load to consume the excess energy rather than to shut the system down. The simulation results proved that SPWM technique is very essential for harmonic reduction and generate required output voltage and frequency to the load. Moreover, the use of LC filter on the load side reduces the harmonic contents which provide the AC voltage supply within acceptable limit.

\section{ACKNOWLEDGMENT}

The author is deeply gratitude to Dr. Myint Thein, Pro-rector, Mandalay Technological University, for his guidance and advice. The author would like to thank to Dr. Yan Aung Oo, Professor, Head of Department of Electrical Power Engineering, Mandalay Technological University, for his kind permission, providing encouragement and giving helpful advices and comments. The author would like to express her most sincere gratitude and appreciation to Dr. Lwin Za Kyin, Associate Professor, Department of Electrical Power Engineering, Mandalay Technological University, for her valuable expertise, advices, and precious insights have been a source of this work and providing guidelines. The author wishes to express her gratitude to all persons who helped directly or indirectly towards the successful completion of this work. Finally and specially, the author wishes to express her deepest gratitude to her parents and friends, for their kindness, understanding, moral support and providing the funding for the large majority of her education.

\section{REFERENCES}

[1] Mittal, R.; Sandhu, K.S.; Jain, D.K. Battery energy storage systemfor variable speed driven PMSG for wind energy conversion. Int. J. Innov. Manag. Tech. 2010, 1, 300-304.

[2] Mahmoud M. Hussein, Tomonobu Senjyu, Mohamed Orabi, Mohamed A.A. Wahab, Mohamed M. Hamada, "Control of a Stand-Alone Variable Speed Wind Energy Supply System", Appl. Sci, pp. 437-456, Vol. 3, April, 2013.

[3] Bhanu R. Bhattatai; “Analysis of a Wind Power Storage System for Load Matching”, August 2009.

[4] Hugo Eduardo Mena Lopez, "Maximum Power Tracking Control Scheme for Wind Generator Systems", Dec, 2007.

[5] Shiladitya Saha, Gaurav Agarwa, Kundan Kumar, "Study and Analysis of Three Phase SPWM Inverter", May, 2012.

[6] Nazmul Islam Raju, Md. Shahinur Islam, Tausif Ali, Syed Ashraful Karim, "Study of SPWM Technique \& Simulation of Designed Analog Circuit (Op-Amp) Controlled Three Phase PWM Inverter with Harmonic Reduction", 978-1-4799-0400-6/13/\$31.00 (C2013 IEEE.

[7] A.Z.M. Shahriar Muttalib, S.M.Ferdous, Ahmed Mortuza Saleque, Nawjif Md. Anamul Hasan, "Design and Simulation of an Inverter with High Frequency Sinusoidal PWM Switching Technique for Harmonic Reduction in a Standalone/Utility Grid Synchronized Photovoltaic System", IEEE/OSA/IAPR International Conference on Informatics, Electronics \& Vision, 978-1-4673-1154-0/12/\$31.00 C2012 IEEE.

[8] C.Y. Wang, Zhinhong Ye \& G. Sinha, Output filter design for a grid connected three phase inverter, Power electronics Specialist Conference, pp. 779-784, PESE 2003.

[9] Samul Araujo\& Fernando Luiz, LCL filter design for grid connected NPC inveters in offshore wind turbins, 7th International conference on Power Electronics, pp. 1133-1138, October 2007. 